\title{
MEDICAL SERVICES - ECONOMIC IMPLICATIONS OF SURGICAL WOUND INFECTIONS. A COMPARATIVE STUDY
}

\author{
Patricia Mihalache \\ Faculty of Economic Sciences, University Lucian Blaga Sibiu, România \\ patricia.mihalache@ulbsibiu.ro
}

\begin{abstract}
Infections associated with the medical and the surgical acts are an important public health problem and quality of medical services, with certain economic implications. Losses from the health state budget are explained by prolonging hospitalization, staff costs, costs of antibiotics, medical tests, and investigations. The present study aims to highlight the importance of avoidable medical costs by reviewing comparative financial data from the national and international literature. The article presents the cost of surgical wound infections comparatively with specific financial data for states such as USA, Germany, UK, Austria, France, Australia and India. In Romania there is an incidence of hospital acquired infections between $1 \%-3 \%$ of cases solved. In the European Union, under the influence of legal provisions, the incidence of these infections is between 5\% and 15\%. Romania, as a Member State of the European Union, will have to comply with reporting requirements for this type of infection (according to the Decision 2119 /98/ EC) and will have to make legislative proposals for economic analyses on medical services and their quality. The case study represents an economic approach of a case of surgical wound infection in a public hospital in Sibiu County (Romania). In Romania there are no financial data available in this field, aspect which will give originality of this paper.
\end{abstract}

Key words: medical services, surgical wound infection, costs

JEL classification: I18

\section{Generally Introduction}

I chose this theme of great importance for the national health status for the originality and multidisciplinary of the topic, under the pressure of mass media that brings to the fore the major deficiencies in the health care system, resulting in the inefficient management of the public funds allocated by the Health Insurance House; especially because of the large sums involved, the health sector accounting for a large part of the budget. Unfortunately its spending has economic implications, as well as social, cultural, etc. effects. Romania, as a member state of the European Union, has to comply with the requirements stipulated in the EC Directives, and the nosocomial infections (HAl) constitutes one of the priorities of the Decision no. 2119/98 / EC (in the EU member states, the incidence of these infections is between $5 \%$ and $15 \%$, in Romania there is an incidence between 1-3\%).

In Romania, hospitals are underfunded, pathology is getting worse, and the healthcare system is in a perpetual reform process, often unsuccessful; for this reason I am trying to bring a contribution by analysing in detail some types of expenditures in the hospital environment, which could be improved. The present study aims to highlight the importance of the medical costs by reviewing comparative financial data from the national and international literature. 


\section{Quantifying financial losses resulting from medical care associated infections worldwide}

Worldwide public health systems financing is done by quality indicators that we can also meet in the health system in Romania, but the difference lies in the critical evaluation of unwanted system losses (Dilara, 2005; Graves, 2004; Hassan, 2010; Yalcin et al., 2002). Studies of immense financial losses in the hospital system through infections have occurred nationwide in the United States of America, the UK, Australia, Taiwan, Turkey, Sweden (Stone, 2005). The main loss of funding is the cost of treating and re-bringing patients with hospital infections (prolonging hospital stay, increasing antibiotic and other medication costs, surgical interventions, disinfectant costs) (Hassan, 2010). The authors of the specialty articles demonstrate that simple observance of infection prevention programs leads to significant savings. A study from Turkey (Dilara, 2005) shows that the average price of a single antibiotic per day, for a single infection, reaches $\$ 94.31$. Taking into account the possibility of prolonging hospitalization, other infections with additional daily costs may also occur (\$ 99 for pneumonia, $\$ 52.37$ for urinary tract infections and $\$ 162.35$ for other cumulative infections) (Smith, 2003). In the United States (Stone, 2009), total annual hospital-related infections amounted for $\$ 6.7$ billion in 2010, and in the UK about $\$ 1.6$ billion. In all studies, at least 1 of 10 hospitalised patients contacted at least one infection (Crotty, 2003); (Heymann, 2014). All of the above studies were reported to national research centers to signal that the initial budget of hospitals did not provide for these losses. In the Northern European countries it is proposed to exclusively fund the hospitalization of the patient without complications, and the additional costs of the infections to be borne by the hospital, the attending physician and even the patient (Neergaard, 2007). There are legislative controversies about who is supporting the avoidable costs.

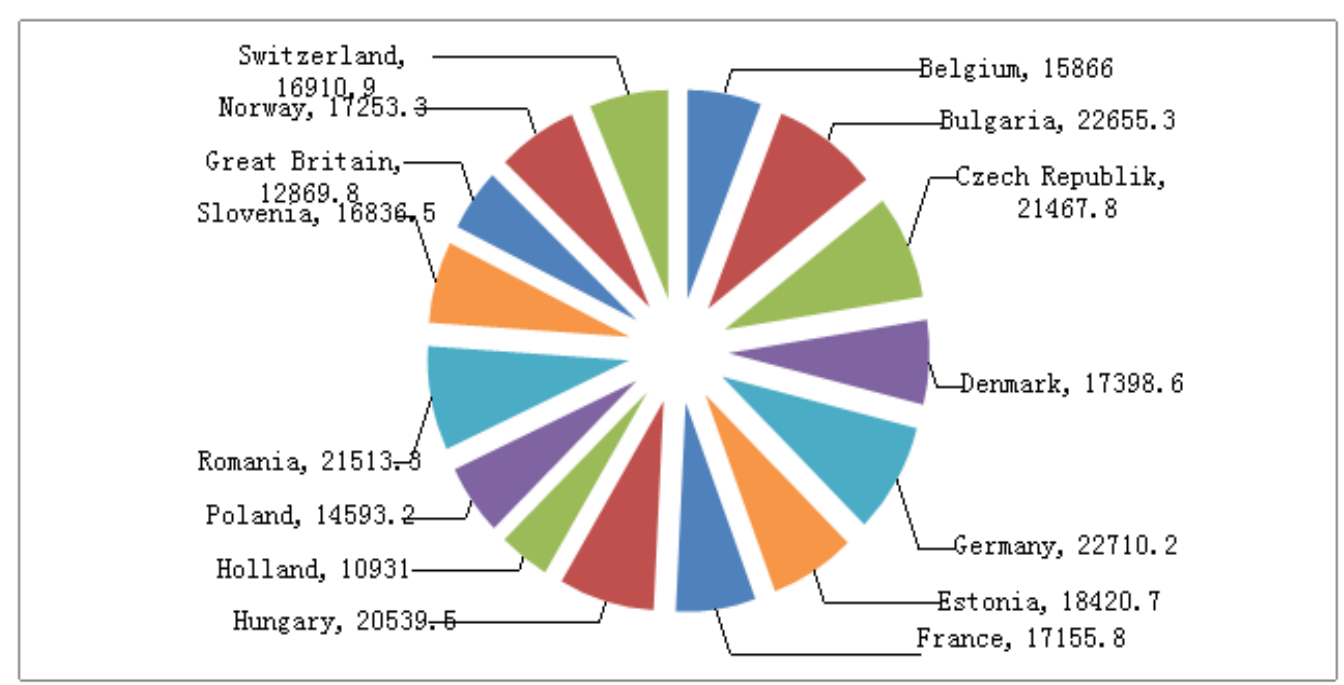

Figure 1: Number of total hospital medical services/100.000 inhabitants Source: Eurostat

The centralizing figure represents all hospital (medical and surgical) medical services provided in different countries. This highlights the importance of the phenomenon studied.

\subsection{Case study - United States of America}

Malone et al. (2002) in a US study from 1986-1996 showed that the disease-associated infection (plague infection) totalized 15,523 cases of infections, out of a total of 593,344 surgeries (with an incidence of $2.6 \%$ ), accounting for $38 \%$ of the total number of inpatient 
infections reported in the United States during that period. The main risk factors in this study were represented by comorbidities (diabetes, obesity, malnutrition, transfusions).

In a private hospital in Pittsburgh McCaughey (2006) describes a case study of a patient with stomach surgery that should have implied a profit for the private hospital of $\$ 5,900$ if the patient had not been infected. Unfortunately, infectious complications (including blood infection) have occurred, resulting in a hospital loss of $\$ 16,000$ after 47 days of additional hospitalization.

McCaughey (2006) shows that in America, every year, 2 million patients contact different forms of hospital infections that compete with the costs of cases of AIDS, cancer, or car accidents. Additional costs in the USA for medical-related infections are of $\$ 30.5$ billion each year, amounts that are unevenly covered by insurance companies and that absorb some of the costs that reduce hospital funding. All of these complications caused 10,800 avoidable deaths (especially for people who were not medical insured). McCaughey is a lawyer specialized in malpractice in the United States of America and was the president of the Committee for the Reduction of Deaths Caused by Medical-Surgical Infections. She has initiated a lot of legislative acts in this respect. Achievements made by Mrs. McCaughey are remarkable for advances in public health in the USA. This initiative must be an example for future European laws for preventing hospital acquired infections.

\subsection{Case study - Germany}

In Germany, Gastmeier (2008) says that, at national level, between 400,000 and 600,000 patients experienced at least one nosocomial infection, of which approximately 10,000 patients died. The second study of the same research (Gastmeier, 2008) was conducted on eight hospitals, from which data were collected from 12,791 patients.

Of a total of 225,000 surgical wound infections, only 160,000 cases were reported at the upper authorities. Studies have found that surgical wound infection is the most common and most serious complication, including avoidable deaths.

\subsection{Case study - Austria}

Author Ojan (2006) from Austria, in collaboration with German authors, studied in 2006 the impact of caring for patients with chronic wounds in the hospital environment. The economic conclusions of the study are as follows: for 4,188 patients, 1,729 days of medical care were recorded, with an extra average daily care cost of 48 Euros, 458 Euros for sanitary facilities, 198 Euros for surgical surgeries and for methods of additional diagnosis of 114 Euro, and staff costs totalled 309 Euros.

\subsection{Case study - Great Britain}

In the extensive and valuable study conducted by Graves and Weinhold (2002), risk factors for contacting an in-hospital infection were calculated based on length of hospitalization, age, sex, type of medical service provided. The results showed that prolonging the duration of hospitalization causes the highest risk of infection (for $10 \%-40 \%$ of patients). All data were calculated on a fictitious patient, because there were no starting data available- they have not been reported quantitatively. It is shown that in England the financial losses from in-hospital infections amounted to $£ 1$ billion in 1999 and the number of deaths to 5,000 (Graves and Weinhold, 2002).

\subsection{Case study - India}

Pramil (2013) conducted a study in a private hospital in Punjab and analysed the costs of several clinical forms of infections associated with medical-surgical act and concluded that about half of the additional costs of these infections are represented by the antibiotics used for treating multiple resistant bacteria from the hospital environment $(124,408 \$$ for 108 
infected patients). The most common bacterial aetiologies were Acinetobacter Baumanii, E. Coli and Klebsiella Pneumoniae.

Binila (2017) reported that $15.2 \%$ of patients in an intensive care unit of a university hospital in India contacted at least one in-hospital infection, which led to an increase in the average hospitalization duration of 7 to 10 days at intensive care and a doubling of the costs necessary for treatment, which financially concerned that department. Interestingly, the respective cases of infection did not have a significant impact on mortality in this section.

\subsection{Case study - Australia}

Graves et al (2017) draw attention on the most important element of the cost of medical-surgical infections, prolonging the length of hospitalization due to these complications. The author claims that the total number of days lost on the entire hospital unit should be reconsidered economically as days of effective treatment for another patient without complications who could benefit from medical services. The major difficulties in the global cost estimate come from the peculiarities of the cases actually treated, through comorbidities. The central element of the cost calculation is the case-study patient.

The findings of the study refer to the development of prophylaxis protocols for these infections, including the standardization of antibiotic treatments.

\subsection{Case study - France}

Lamarsalle (2013) conducted a retrospective study of the cost of surgical wound infections since 2009 and concluded that $3 \%$ of all surgical procedures in France presented infectious complications that led to total costs of 57,892,715 Euros, with tripling duration of hospitalization standards and increasing the risk of death by about four times. To reduce these costs surgical sutures with triclosan (antibacterial substance) were performed. The method could lead to a reduction in the number of surgical wound infections - by $20-30 \%$, with possible savings of 11.548.057 Euros.

\section{Health-associated infections in Romania- situation analysis}

Infections associated with the medical and the surgical act are poorly reported in Romania, compared to other EU countries and the USA. Thus, by 2015, the Ministry of Health records a total of 57,088 cases of such infections in Romania. According to the National Center for Statistics of Public Health in Romania, the average annual number of cases is 8,891 , with a minimum in 2010 (8,105 cases) and a maximum reported in 2008 of 9,677 cases, without analysing the economic implications. 


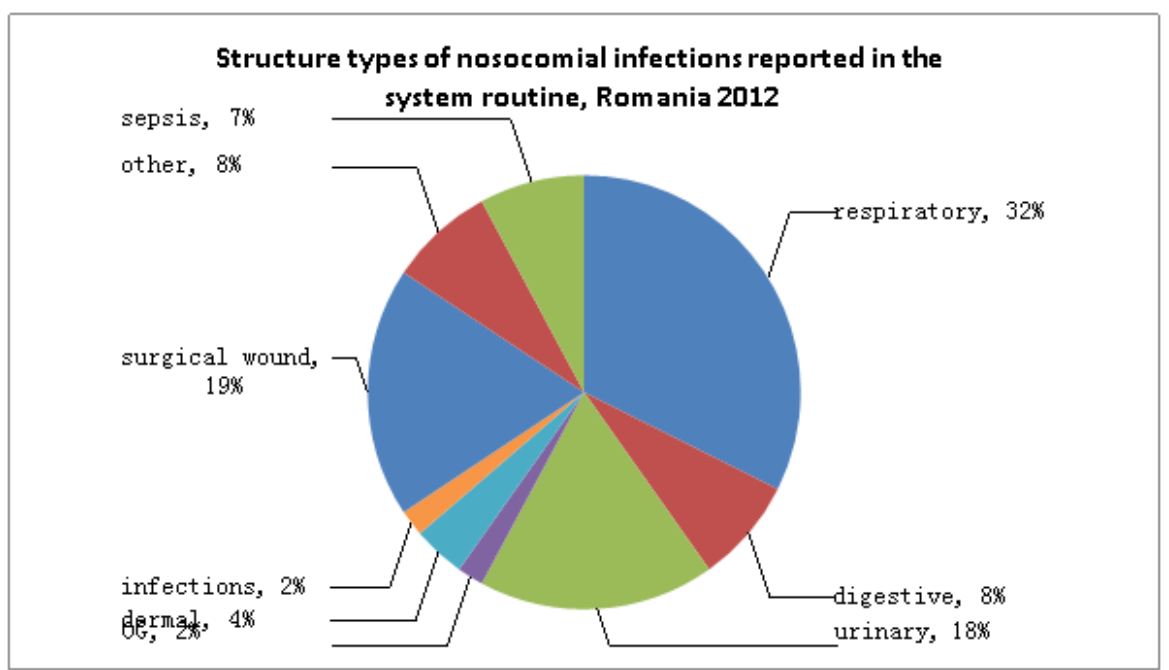

Figure 2: In-hospital infections reported in Romania

Source: Centrul Național de Statistică și Informatică în Sănătate Publică (CNSISP)

A possible sub-declaration of cases in Romania could be explained by the large number of unjustified admissions for pathologies that could be solved at the level of family doctors, but also by the prejudices of doctors who do not want to compromise the reputation of the department or hospital. Hospital acquired infections hidden cost issues have been taken over by the media that signals these dangers regarding the safety and quality of the medical act. This fact has spurred the appearance of the legislative document MS (Ministry of Health) no. 1101 of 2016, which regulates the declaration, investigation, prevention and control of in-hospital infections.

One step ahead in the hospital acquired infections control was represented by MS Order no. 916 of 2006, which proposes the establishment of a special prevention service for medical-related infections, as a separate department in each hospital, a service that has the obligation to trace, investigate and report the cases of infection. National data shows that one third of these infections can be countered by prophylactic hygiene measures and hospital disinfection measures, but unfortunately a third of the reported cases can not be avoided by any method, probably due to underfunding of medical services (Mihalache, 2013).

These centralized data at national level have again highlighted the importance of the quality of medical and medical services, the respective infections being a risk factor for the patient and for the economic aspect of financing the medical system.

\subsection{An example of avoidable costs of a surgical wound infection from a public hospital in Romania (in 2017)}

We have analysed a case of surgical wound infection - the department of general surgery from a public hospital (ward with an average cost of day hospitalization $331.96 \mathrm{RON}$ ), based on data from the station and the hospital information system. Every case is being registered in an informatics data basis of the hospital, with all the information about the pathology and the costs.

Each hospital has a computer system that manages primary data on hospitalized patients in the form of continuous hospitalization (with hospitalization over 12 hours) and patients undergoing day hospitalization (investigated for up to 12 hours of the hospitalization). 
In developed countries it tends to day-care medical services to avoid the infectious costs of the medical-surgical act. It also reduces the cost of effective hospitalization, staff costs, medical supplies, and medication.

The administration of the system later allows for synthesis on the duration of hospitalization, the cost of materials and drugs used, the medical services provided and the calculation of the costs of hospitalization, which will be the basis of the state budget financing for the following year, based on DRG (Diagnosis Related Groups, www.drg.ro). It is possible to calculate the costs per patient, per section, in calendar years, by making a parallel between the medical services and the financial support from the state budget.

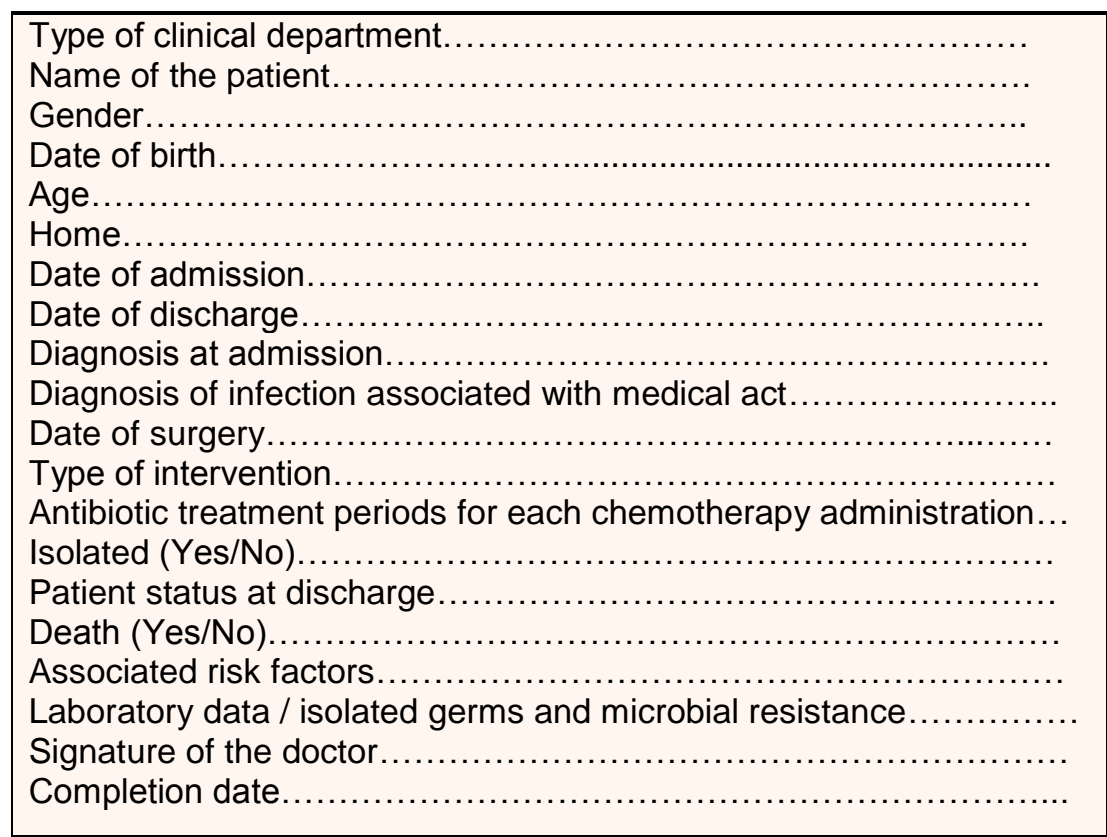

Figure 3: Data type of reporting cases

Data type of reporting cases of infections associated with medical and surgical act - HAl is imposed by the Minister of Health no. 1101 of 2016, a document obliging healthcare professionals to declare and investigate those cases that compromise the safety and quality of medical care and generate unjustified costs. In the hospital's computer system, there is a HAl folder that centralizes the nosocomial infections of each department.

According to the aforementioned Order, a unique register of all cases of infections related to the medical act of the respective hospital, declared (denied or confirmed) is made. Cases and suspected infections are reported monthly and numerically to the Public Health Directorate, probably to create a future national database, taking into account pressures from European legislation.

On the website of each hospital in Romania (another aspect of the system that makes public the decisional transparency) the average duration of hospitalization, per department, for the current year, is stated, within the limits of 3-6 9 days, depending on the pathology of the department. 
Table 1: Example from a surgical department; hidden costs of a surgical wound infection in a public hospital (initial research-example- patient S.I., 62 years old, male

\begin{tabular}{|c|c|}
\hline $\begin{array}{c}\text { Cost surgical patient without } \\
\text { wound complications }\end{array}$ & $\begin{array}{c}\text { Cost of patient S.I. with surgical } \\
\text { wound infection }\end{array}$ \\
\hline Standard hospitalization $=6.9$ days & $\begin{array}{c}\text { Infection surgical wound }=51 \text { days of } \\
\text { hospitalization } \\
\text { (Excess }=44.1 \text { days) }\end{array}$ \\
\hline $\begin{array}{c}\text { DRG cost of hospitalization }=331.96 \\
\text { RON }\end{array}$ & $\begin{array}{c}\text { Real cost / day of hospitalization for } \\
\text { infectious complication }=764 \\
\text { RON(real cost / day } 2.3 \text { times higher } \\
\text { than DRG) }\end{array}$ \\
\hline $\begin{array}{c}\text { Total hospitalization cost }(\mathrm{DRG})= \\
2290.524 \mathrm{RON}\end{array}$ & $\begin{array}{c}\text { Total expenses for infection } \\
\text { complications }=35.994 .11 \mathrm{RON} \\
\text { (avoidable expenses 33.703.86 RON) }\end{array}$ \\
\hline
\end{tabular}

Source: own research

In conclusion, the day of hospitalization with the infectious complication of the surgical act actually costs 2.3 times more than the amount settled by CNAS (331.96 RON / day).

Extending the length of hospitalization for a patient with infectious complications blocks the provision of medical services to a patient who could have been hospitalized on the same hospital bed and was unable to receive the necessary care. This represents a second financial loss through the unusual use of the hospital bed, with the alteration of the DRG performance indicators, resulting in a sub-financing of the department and the hospital.

The simple presentation of this case study is an alarm signal about avoidable expenditures in the health care system.

\section{Conclusion}

These centralized data at national level have again highlighted the importance of the quality of medical services and of the medical act, the respective infections being a risk factor for the patient and for the economic aspect of financing the medical system.

The future research directions of the thesis will focus on the financing of public hospitals and the economic impact of non-quality risk factors (hospital acquired infections).

Research limitations include lack of financial data of these complications, which are not included in the revenue and expenditure of the health unit. Future research may show the importance of quantifying unwanted expenses.

\section{Acknowledgements}

Thanks to all the professors of the Faculty of Economic Sciences ULB Sibiu, and especially to my scientific advisor Prof.Univ.Dr.Ilie Rotariu.

\section{References}

Binila C., Kurien T., Thambu D., Hema P., Lakshmanan J., John V. P. 2017. Attributable cost of a nosocomial infection in the intensive care unit: A prospective cohort study, World Journal of Critical Care Medicine, 6(1), pp. 79-84

Crotty, M. 2003. The Foundations of Social Research. London: Sage. 
Dilara I., Saba R., Gunseren F., Gozde O., Turhan,O., Yalcin, A.N., Mamikoglu, L.2005. Daily antibiotic cost of nosocomial infections in a Turkish university hospital, BMC infection diseases, 5(5), 1-6.

Graves N., Weinhold D. 2002. Estimating the costs of hospital acquired infection, American Journal of Infection Control, pp.2-4.

Graves, N, Harbarth, S, Beyersmann, J, Barnett, A, Halton, K, Cooper, B., 2010. Estimating the cost of health care-associated infections: mind your p's and q's. Clinical Infectious Diseases, 50, pp.1017-1021.

Graves N. 2004. Economics and Preventing Hospital-acquired Infection, Emerging Infectious Diseases, 10(4), pp. 561-566.

Hassan M., Tuckman H.P., Patrick R.H., Kountz D.S., Kohn, J.L. 2010. Cost of hospital acquired infection, Hospital Topics, 88, pp. 82-89.

Heymann D.L., Reinhardt K. 2014. Emerging Infections, the International Health Regulations, and Macro-Economy, in Encyclopedia of Health Economics, Culyer A.J. (Ed), pp. 272-276, New York: Elsevier.

Gastmeier P., Geffers C. 2006. Nosokomiale Infektionen in Deutschland: wie viele gibt es wirklich? Eine Schatzung fur das Jahr 2006, Deutsch med wochenschr 2008; 133, Georg Thieme Verlag KG: Stuttgart, New York, pp.111-1115.

Lamarsalle L., Hunt B., Schauf M., Szwarcensztein K. and Valentine W.J. 2013. Evaluating the clinical and economic burden of healthcare-associated infections during hospitalization for surgery in France, Epidemiology \& Infection, 141, pp. 2473-2482.

Malone, D.L., Genuit, T., Tracy, J.K., Gannon, C., Napolitano, L..M. 2002. Surgical Site Infections: Reanalysis of Risk Factors, Journal of Surgical Research, 103(1), pp. 89-95.

McCaughey B. 2006, Unnecessary Death - The Human and financial cost of hospitals, 2nd Edition, Rid Committee to reduce infection death, hospitalinfection.org

Mihalache D.D. 2013, Infecții intraspitalicești în România- miracol pe hârtie. Viața Medicală, 43(1240), http://www.viata-medicala.ro/*articlelD_7611-dArt.html, [accessed 15 October 2017]

Neergaard H., John P. 2007, Handbook of Qualitative Research Methods in Entrepreneurship. Northampton: Edward Elgar Publishing.

Ojan A., Daeschlein G., Kramer A. 2006. Die Bedeutung der infizierten Problemwunde für den Hygieniker und Mikrobiologen sowie ökonomische Aspekte der chronischen WundeGMS Krankenhaushygiene Interdisziplinär,1(1).

Tiwari, P., Rohit, M. and Pharm, M. 2013. Assessment of Costs Associated with Hospital-Acquired Infections in a Private Tertiary Care Hospital in India, Value in Health Regional Issues, 2, 87-91.

Smith M. 2003. Research Methods in Accounting. London: Sage.

Stone W. P. 2009. Economic burden of healthcare-associated infections: an American perspective, Expert Review of Pharmacoeconomics \& Outcomes Research, 9(5), pp.417-422.

Yalcin A.N., Turgut H., Cetin C.B., Tefci F. 2002, Cost of antimicrobial therapy in nosocomial infections, Turkish Journal of Hospital Infection, 6, pp.41-45.

Monitorul Oficial al Romaniei, Hotararea nr. 629/2015 privind componența, atribuțiile, modul de organizare și funcționare ale Autorității Naționale de Management al Calității în Sănătate, republicata in anul 2017 in Monitorul Oficial al Romaniei sub forma Legii nr. 185/2017 privind asigurarea calității în sistemul de sănătate

Ministerul Sanatatii (Ministry of Health), Ordin nr. 916/2006 din 27/07/2006 Publicat in Monitorul Oficial, Partea I nr. 759 din 06/09/2006 privind aprobarea Normelor de supraveghere, prevenire şi control al infecţiilor nosocomiale în unităţile sanitare Ministerul Sanatatii (Ministry of Health) Ordinul nr. 1101/2016 privind aprobarea Normelor de supraveghere, prevenire și limitare a infecțiilor asociate asistenței medicale în unitățile sanitare 
Centrul National de Supraveghere si Control al Bolilor Transmisibile www.cncsbt.ro, accessed on 12th of October 2017

Centrul Național de Statistică și Informatică în Sănătate Publică (CNSISP), http://cnsisp.insp.gov.ro/, accessed on 12th of October 2017.

\section{Bio-note}

Patricia Mihalache is a PhD student at the Faculty of Economic Sciences, University Lucian Blaga Sibiu and her main research topic of study is the economic analysis of medical services in Romania, compared with similar services abroad. 